\title{
Submental Intubation for Panfacial Fractures- Review of Techniques and Outcome in 34 Patients
}

\author{
Dr Sewak Ram Verma ${ }^{1}$, Dr Deepak Kothari ${ }^{2}$, Dr Basant Chaurasia ${ }^{1}$ \\ Assistant Professor ${ }^{1,2}$, CM Medical College, Durg, Chhattisgarh, India
}

\begin{abstract}
Aim: To study the results and outcomes of submental intubation in 34 cases of multiple facial fractures. Material and methods: 34 cases of panfacial fractures were operated between 2014 to 2016. All of them were managed intraoperatively with submental intubation. We review the literature and compare the outcome of submental intubation in our series of cases.

Results: All the cases except two were extubated immediate post operatively and had very good outcome. There we faced minor complications in only 2 of the patients.

Conclusion: Submental intubation is a safe, effective and appropriate method for panfacial fractures and avoids the need for tracheostomy in such patients.
\end{abstract}

Keywords: Submental intubation, panfacial fractures, tracheostomy.

\section{Introduction}

First time in 1986, Altemir [1], described the submental route for endotracheal intubation. Submental approach provided a secure airway, an unobstructed intraoral surgical field and allowed maxillomandibular fixation [2,3] where dental occlusion needed (precludes the use of oral intubation) while avoiding the drawbacks and complications of tracheostomy. Nasotracheal intubation is not possible in the presence of fractures of nasal bone fracture, skull base fractures and cerebrospinal fluid rhinorrhoea. In such cases any attempt towards nasotracheal intubation can lead to passage of tube into the cranium, meningitis, sepsis, sinusitis etc.

In situations where maxillomandibular fixation is required and nasoendotracheal intubation is contraindicated, a cricothyrotomy or tracheostomy has been the traditional method of airway control.[4] Submental intubation technique consists of passing the tube through the anterior floor of mouth, allowing free intraoperative access to oral cavity and nasal pyramid without endangering patients with skull base trauma.

The purpose of this study was to describe the outcome of a series of 34 patients who had submental intubation for surgical correction of panfacial trauma [5]. We have also added some modifications in the original technique described.

\section{Materials And Method}

From 2014 to 2016, 34 patients benefited from submental intubation. 29 patients were male and 5 were females with the age range from 18 to 57 years. All patients were victims of facial trauma due to road traffic accident. Most of the facial injuries were a combination of fractures affecting the dental occlusion (maxillary fractures of Le Fort I type, mandibular fractures or alveolar fractures) and associated with another fracture dislocating either the anterior skull base (Le Fort II or III fractures) or the nasal pyramid (nasoorbitethmoidal fractures).

\section{Operative Procedure}

All the subjects had their trachea intubated orally by standard direct laryngoscopy after induction of general anaesthesia with a reinforced (spiral-embedded) tracheal tube having an internal diameter of 7.5 or 8.5 $\mathrm{mm}$. The orotracheal intubation was then converted to a submental endotracheal intubation by using the following procedure.

Under sterile conditions 2\% with 1:20000 adrenaline was infiltrated at the incision site . We modified the standard incision by taking it $2 \mathrm{cms}$ lateral to midline on the side opposite the fracture of mandible. A curved haemostat was passed from the submental incision through the subcutaneous layer, platysma, mylohyoid muscle, submucosal layer and mucosa. The haemostat was opened to create a soft tissue passage for the endotracheal tube. With the curved haemostat, the deflated pilot tube cuff was passed extraorally. Before intubating, we used to cut the wings of the connector of endotracheal tube to facilitate its passage. Then the endotracheal tube was disconnected from the breathing circuit, the tube was then manually stabilized and the tip of the endotracheal tube gently pulled out through the submental incision with the help of a curved haemostat. The tube was reconnected and secured to the skin of the submental area with 3-0 Silk. 
Anatomical reduction and rigid internal fixation of the maxillofacial fractures were achieved by using miniplates osteosynthesis. Temporary maxillomandibular fixation was used in all cases.

At the end of the surgery, the maxillomandibular fixation was released and the tube was pulled out from the same submental incision. The submental skin incision was closed with interrupted nylon sutures and the intraoral incision closed with vicryl sutures.

The tube was left in place only in two patients who had Head Injury associated with these fractures and was removed after 2 days.

\section{Results}

Table 1- Patient's demographical and clinical data

\begin{tabular}{|c|c|c|c|c|c|}
\hline AGE & Sex & Type of fracture & $\begin{array}{l}\text { Intraop } \\
\text { complication }\end{array}$ & $\begin{array}{l}\text { Post op } \\
\text { complication }\end{array}$ & $\begin{array}{l}\text { Post op } \\
\text { ventilation }\end{array}$ \\
\hline 26 & M & $\begin{array}{l}\text { Mandible and } \\
\text { maxilla }\end{array}$ & None & None & No \\
\hline 34 & M & $\begin{array}{l}\text { Lefort II and } \\
\text { mamdible }\end{array}$ & None & None & No \\
\hline 55 & $\mathrm{M}$ & $\begin{array}{l}\text { NOE and } \\
\text { mandible }\end{array}$ & None & Hematoma & No \\
\hline 32 & $\mathrm{~F}$ & $\begin{array}{l}\text { Lefort III and } \\
\text { mandible }\end{array}$ & None & None & Yes \\
\hline 57 & $\mathrm{M}$ & $\begin{array}{l}\text { Skull base and } \\
\text { mandible }\end{array}$ & None & None & No \\
\hline 42 & M & $\begin{array}{l}\text { Nasal and } \\
\text { mandible and } \\
\text { zygoma }\end{array}$ & None & None & No \\
\hline 31 & M & $\begin{array}{l}\text { Lefort II and } \\
\text { mandible }\end{array}$ & None & None & No \\
\hline 41 & M & $\begin{array}{l}\text { Lefort I and } \\
\text { mandible }\end{array}$ & None & None & No \\
\hline 32 & M & $\begin{array}{l}\text { LefortI and } \\
\text { mandible }\end{array}$ & None & None & No \\
\hline 41 & $\mathrm{~F}$ & $\begin{array}{l}\text { NOE and } \\
\text { Mandible }\end{array}$ & None & None & No \\
\hline 18 & M & $\begin{array}{l}\text { Lefort III and } \\
\text { Mandible and } \\
\text { zygoma }\end{array}$ & None & $\begin{array}{l}\text { Hypertrophic } \\
\text { Scar }\end{array}$ & No \\
\hline 26 & $\mathrm{~F}$ & $\begin{array}{l}\text { Lefort I with } \\
\text { dentoalvolar and } \\
\text { zygoma }\end{array}$ & None & None & No \\
\hline 36 & M & $\begin{array}{l}\text { Lefort I and } \\
\text { Mandible }\end{array}$ & none & None & No \\
\hline 28 & M & $\begin{array}{l}\text { Lefort I and } \\
\text { Mandible }\end{array}$ & None & None & No \\
\hline 53 & M & $\begin{array}{l}\text { Skullbase and } \\
\text { Mandible }\end{array}$ & None & None & Yes \\
\hline 27 & M & $\begin{array}{l}\text { Lefort I and } \\
\text { Mandible }\end{array}$ & None & None & None \\
\hline 19 & M & $\begin{array}{l}\text { Lefort I and } \\
\text { Mandible }\end{array}$ & None & None & No \\
\hline 43 & $\mathrm{M}$ & $\begin{array}{l}\text { NOE and } \\
\text { Mandible }\end{array}$ & None & None & None \\
\hline 51 & $\mathrm{~F}$ & $\begin{array}{l}\text { Lefort I and } \\
\text { Mandible }\end{array}$ & None & None & No \\
\hline 23 & M & Panfacial & None & None & None \\
\hline 33 & M & $\begin{array}{l}\text { Lefort I and } \\
\text { Mandible }\end{array}$ & None & None & None \\
\hline 21 & M & $\begin{array}{l}\text { Lefort I and } \\
\text { Mandible and } \\
\text { Nasal } \\
\end{array}$ & None & None & No \\
\hline 40 & M & $\begin{array}{l}\text { NOE and } \\
\text { mandible }\end{array}$ & None & None & No \\
\hline 27 & M & Panfacial & None & None & No \\
\hline 33 & M & $\begin{array}{l}\text { LefortI and } \\
\text { Mandible }\end{array}$ & None & None & No \\
\hline 26 & M & $\begin{array}{l}\text { Nasal and } \\
\text { Mandible }\end{array}$ & None & None & No \\
\hline 38 & $\mathrm{~F}$ & $\begin{array}{l}\text { Condylar and } \\
\text { Palate }\end{array}$ & None & None & No \\
\hline 46 & $\mathrm{M}$ & Panfacial & None & None & No \\
\hline 19 & $\mathrm{M}$ & Lefort I and & None & None & No \\
\hline
\end{tabular}




\begin{tabular}{|l|l|l|l|l|l|}
\hline & & Mandible & & & No \\
\hline 30 & M & $\begin{array}{l}\text { NOE and } \\
\text { Mandible }\end{array}$ & None & None & No \\
\hline 22 & M & $\begin{array}{l}\text { Lefort II and } \\
\text { Mandible }\end{array}$ & None & None & No \\
\hline 23 & M & $\begin{array}{l}\text { Lefort III and } \\
\text { Mandible }\end{array}$ & None & None & No \\
\hline 37 & Mandible and & None & None & No \\
\hline 31 & M & Pangoma & None & None & \\
\hline
\end{tabular}

There was no difficulty in passing the tube through the floor of mouth, and the total duration of submental intubation procedure ranged from 6 to 10 minutes. We used to cut the wings of the standard connector before doing intubation because connector removal is associated with loosening and exposure of wires of the tube. Time period for disconnection from the ventilator ranged from 60 to 90 seconds, and there was no significant oxygen desaturation in any subject during the procedure.

Placing the tube lateral to the midline and opposite to the direction of fracture has helped us to manipulate the fracture segments easily to obtain good results. Only two patients in the present study required postoperative ventilation. These two patients had an associated head injury and where not fully oriented at the time of surgery, but because of multiple displaced fractures, they were taken for surgery under due risk and kept intubated for two days and later the tube was removed via submental route only. The recovery was uneventful. Rest of the 32 patients were extubated in the operating room itself. The extubation was from submental route only.

Subjects were evaluated in the postoperative period at 1 week, 1 month and 6 months. No motor or sensory salivation deficit was found. We routinely close the defect of floor of the mouth to decrease the risk of bleeding and hematoma formation. Only one patient developed a hematoma - it was drained after 2 days and the recovery was uneventful.

The scar has been well accepted by all the patients with only one patient developing hypertrophic scarring, who had a keloidal tendency all over his body.There was no incidence of superficial skin infection, damage to the tube apparatus, fistula formation, right mainstem bronchus tube dislodgement/obstruction, accidental extubation or mucocele formation.

\section{Discussion}

Management of the airway is always a primary concern during any maxillofacial surgery. Implementing a safe and acceptable alternative to tracheostomy for short-term airway management is a desirable objective for optimal management of complex craniofacial injuries. Nasotracheal intubation may best be avoided in these groups of patients because of reported dangers of nasotracheal intubation in the presence of midfacial and basilar skull fractures, such as cranial intubation, epistaxis, trauma to the pharynx, pressure necrosis of external nares, otitis media, sinusitis, sepsis and inability to pass a tube through nasal passages. [6-8]

The alternative of orotracheal intubation significantly facilitates manoeuvres for reduction and stabilization of the jaws, which often requires immobilization with arch bars and wires. Doing oral intubation will never give optimal results in these patients because of the requirement of intermaxillary fixation.

Tracheostomy may cause many general, local, early and late complications like cardiac arrest, air embolism, subcutaneous or mediastinal emphysema and recurrent laryngeal nerve damage with all its consequences. $[7,9,10]$ Late complications include laryngeal or tracheal stricture, haemorrhage from large blood vessels caused by decubitus of vessel walls, tracheo-oesophageal fistula, extensive granulation and inflammatory complications.[11] Due to these potential complications, tracheostomy for airway management was avoided

Both retromolar intubation [12] and nasal tube switch techniques [13] have its own set of complications and difficulties. Since the first description, submental intubation has undergone various modifications and found new indications.[14] It could be safely used in patients with midfacial or panfacial fractures with possible base of skull fractures, as well as in patients undergoing elective Le Fort osteotomies or simultaneous elective mandibular orthognathic surgery and rhinoplasty procedure.[15,16] In our present series, submental intubation was possible in all the patients without any major complication, allowing proper manipulation of the fracture fragments, satisfactory achievement of occlusion, establishment of maxillomandibular fixation and complete assessment of facial symmetry. Moreover, extubation was found to be simple and the cosmetic results were acceptable, with no long-term morbidity.

We have done two modifications in the original technique:

First, we always cut the wings of the connector of the armoured tube. It not only helps in easy passage of the tube, but also reduces the chances of tube damage on removal of snugly fit connector. On forceful removal, the wires of the tube can easily get damaged. 
The second modification we do is to place the incision and tube far laterally, opposite to the site of fracture of mandible. Even in cases of comminuted fractures, placing the tube laterally helps in proper alignment of the mandible segments, optimal reduction and occlusion. And we believe that because we take an oblique route, the chances of fistula formation is also reduced to minimal.

In our series, no episodes of compromised airway or arterial desaturation occurred during the procedure. Other possible potential complications such as orocutaneous fistula, trauma to the submandibular and sublingual glands or canals, damage to the lingual nerve, were also not observed. Only one patient developed hematoma at the tube site, which was recognised early and drained. One patient developed hypertrophic scar over the incision site, but he had a tendency of keloid formation all over his body.

So here we conclude that, this study shows good results with the use of submental endotracheal intubation for surgical treatment of 34 patients with panfacial fractures. In all cases, the planned surgery was completed without interference from the artificial airway and, most importantly, without compromising the airway with two modifications to avoid major complications.

\section{References}

[1]. Hernández Altemir F. The submental route for endotracheal intubation: A new technique. J Maxillofac Surg. 1986;14:64-65.

[2]. Markowitz BL, Manson PN. Panfacial Fractures: Organization of treatment. Clin Plast Surg.1989;16:105-14

[3]. Shumrick KA, Kersten RC, Kulwin DR, Sinha PK, Smith TL. Extented access internal approaches for the management of facial trauma. Arch Otolaryngol Head Neck Surg. 1992;118:1105-12.

[4]. Phero JC, Weaver JM, Peskin RM. Anesthesia for maxillofacial/mandibular trauma. In: Benumof JL, editor. Anesthesiology clinics of North America. Anesthesia of otolaryngologic and head and neck surgery.Philadelphia: Saunders; 1993. pp. 509-23.

[5]. Adamo Arthur K. Intraoperative airway management with Panfacial Fractures, Alternative Approach. J Craniomaxillofacial Surg. 1996; 2:30-35.

[6]. Schultz RC. Nasotracheal intubation in the presence of facial fractures. Plast Reconstr Surg. 1990;86:1046.

[7]. Fonseca R, Walker R. Oral and maxillofacial trauma. 2nd ed. Philadelphia: WB Saunders; 1997. pp. 105-35.

[8]. Hall DB. Nasotracheal intubation with facial fractures. JAMA. 1989;261:1198.

[9]. Gluckman JL, Mangal AK. Laryngeal trauma. In: Paparella MM, Shumrick DA, Gluckman JL, Meyerhoff WL, editors. Otolarngology, Vol III: Head and neck. Philadelphia PA: Saunders; 1991. p. 2231.

[10]. Mc Clelland RM. Complications of tracheostomy. Br Med J. 1965;2:567-9.

[11]. Glazur J. Respiration via tracheostomy - Advantages, disadvantages and complications. Anest Reanim.1971;3:451.

[12]. Martinez- Lage JL, Eslava JM, Cebrecos AI, Marcos O. Retromolar intubation. J Oral Maxillofac Surg.1998;56:302-6.

[13]. Werter JR, Richardson G, Mcilwain MR. Nasal tube Switch: Converting from nasal to an oral endotracheal tube without extubation. J Oral Maxillofac Surg. 1994;52:994-6.

[14]. Green JD, Moore UJ. A modification of submental intubation. Br J Anaesthesia. 1996;77:789-91.

[15]. Biglioli F, Mortini P, Goisis M, Bardazzi A, Boari N. Submental orotracheal intubation: An alternative to tracheotomy in transfacial cranial base surgery. Skull Base. 2003;13:189-95. 